原著論文

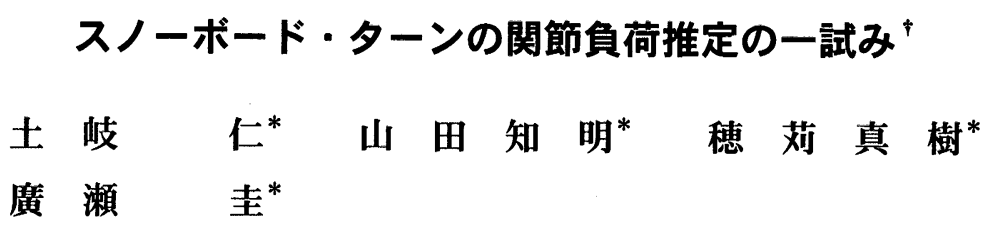

\title{
An Attempt at Estimation of Joint Load on Snowboarding Turn ${ }^{\dagger}$
}

\author{
Hitoshi DOKI* , Tomoaki YAMADA* , Masaki HOKARI* \\ and Kiyoshi HIROSE*
}

\begin{abstract}
In this paper, we propose an attempt at dynamics analysis and measurement method of snowboarding turn that is performed on an outside actual snowfield. We assumed the torso and lower limbs of a snowboarder to constitute a three-dimensional rigid link model. This model consists of an upper body, a lumbar part, a pair of thighs, lower thighs and feet and has total 20-degree-of-freedom. Then, joint moments were calculated by applying the Newton-Euler method in order to estimate the load that affects each joint. The measurement system utilized a three-dimensional gyro sensor to measure physical exertion of snowboarder and a 6-axis force sensor that measured reaction force from the snow surface. By applying this measurement system, a measurement experiment was carried out at a ski area. The measurement results (angular velocity, angle and joint moment) indicated the major features of snowboarding turns and we could quantify characteristics and estimate the loads exerted on snowboarders in each phase of turning.
\end{abstract}

Key words : Snowboarding Turn, Newton-Euler Method, Gyro Sensor, 6-axis Force Sensor

1.はじめに

スノーボードの指導は主に見た目，すなわち 定性的な評価に頼ってきた。 それは指導者の経 験や理論により総合的に滑りを見ることで指導 を行っており，人によって表現方法がさまざま である.

スノーボーダーの運動解析に関する研究とし て, 屋内におけるスノーボード操作の計測が行 なわれている12). また, スノーボード・ター ンのメカニズムを解明するために, ターン動作
のシミュレーション3)，解析用スノーボードロ ボットの開発も進められている゙). しかし, こ れらの研究は, 実際の雪面を滑走するスノー ボーダーの運動や生体負荷の情報が含まれてお らず，用具の設計・開発やバイオメカニクス解 析には不十分である.

筆者らは，磁気式三次元位置センサ，ビデオ カメラ, 6 軸力覚センサを用いて, 屋外で広範 囲にわたってスキーヤーやスノーボーダーの運 動と作用する外力を計測できるシステムを構築 し, 実際の雪面上を滑走する場合の生体運動解

\footnotetext{
“原稿受付 2006 年 9 月 14 日

*秋田大学 T 010-8502 秋田県秋田市手形学園町 1-1

*Akita University, 1-1, Tegata Gakuen-machi, Akita, Akita, Japan (010-8502)
} 
析を行ってきた ${ }^{5)-9)}$. しかし, この磁気式三次 元位置センサは機器自体が大きく重いため, 被 験者の運動を拘束する恐れがある，また，この センサはトランスミッタと呼ばれるセンサを基 準とした部分のみしか計測できず，慣性系にお ける運動を計測するためには余分なシステムを つける必要がある。そのために，ほほ無拘束状 態で計測できるビデオカメラを利用した DLT 法を併用したが，撮影範囲が限られ滑走中の回 転運動により画像中の注目点が身体裏側に隠れ てしまうことがある。ささにスキ一場のような 広大な範囲で, 天候が変わりやすい場所では精 度よく計測することは困難である。また，磁気 式三次元位置センサとDLT 法は並進運動を計 測し、リンクモデルと運動学から回転運動を求 める逆運動学問題となり, 非線形方程式の数値 解法と多くの計算処理が必要となる.

本論では，スキー場のような屋外で，かつ広 範囲にわたつてスノーボーダーのターン運動お よび雪面からの反力を計測できるジャイロセン サと 6 軸力覚センサを用いたシステムを新たに 提案する.さらに，筆者らの先行研究「スキー 滑走における筋張力と拮抗筋作用の検討」では, 整地された緩斜面で連続ターンを行ったときの 人体の各関節に作用するモーメントを動力学モ デルと準静力学モデルで比較した結果，ほぼ 一致することを報告した ${ }^{5)}$ 。これより，本論の 実験範囲内で必ずしも静止座標系でスノーボー
ダーに作用する慣性力を考慮しなくても, ボー ドに設置した力覚センサで得られる慣性力を含 んだ情報を用いて生体内負荷を動力学的に推定 する一手法について述べる。

\section{2. スノーボードのターン運動と問題}

\section{1 スノーボードのターン運動}

スノーボードは，サーフィンやスケートボー ドに代表されるように進行方向に対して半身の 姿勢をとるサイドウェイスタンスという左右非 対称の滑走フォームを持つスポーツであり, バ ランスがとても重要となる. Fig.1にスノーボー ドの基本ターン一連の動作を示す。（a）のター ンはフロントサイドターンと呼ばれ，爪先側に 荷重をかけてターンを行う。一方，（b）のター ンはバックサイドターンと呼ばれ，踵でエッジ ングを行い, ターンをする。雪面に対してボー ドの片側のエッジだけが雪面に触れる状態の 「角づけ」を行い,「荷重」を行うことによりボー ドをたわませてターンを行う。この状態で体の 「ひねり」を加えることで, ターンをコントロー ルする. したがって,この「角づけ」・荷重」・「ひ ねり」の 3 つの要素がターンにおいて重要とな る.

\section{2 本論で取り組む問題}

スノーボードのターン運動は斜面における並 進運動とスノーボーダーの各関節の回転運動に

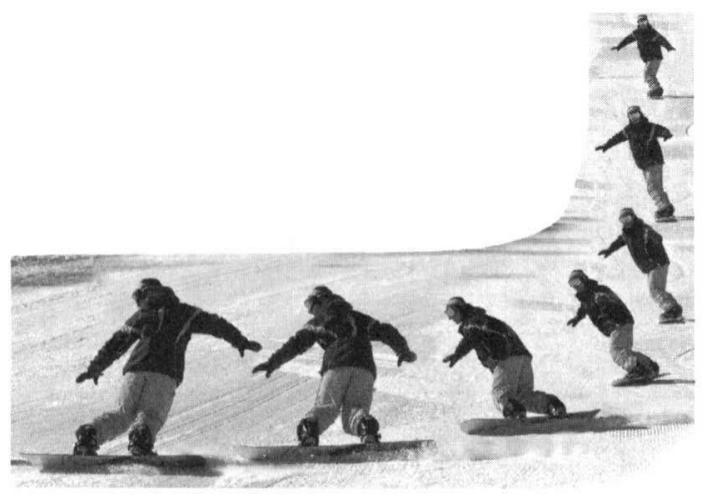

(a) Front-side turn

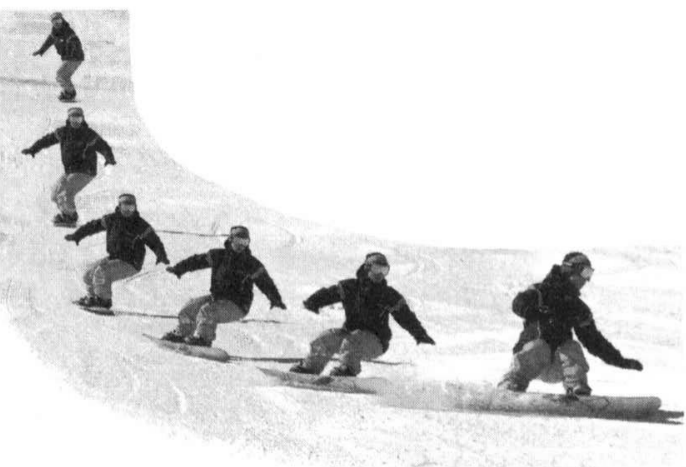

(b) Back-side turn

Fig.1 Snowboarding turn 
より構成されている. 本論ではその回転運動に 着目し計測を行い, スノーボードのターン運動 を解析する．スノーボードは雪上・斜面という 不安定な場所で，両足を一枚のボードに固定し て滑走する．そのため全身でのバランスが重要 となってくるが，その中でも特に重要となって くるのが雪面と一番近い脚部である．脚部をモ デル化, 解析することが必要である.さらに, 脚部のひねり運動に加えて上体のひねり運動も スノーボードでは重要であるため, 上体部・腰 部を含めたモデルを構築する必要がある.

以上より，本論は整地された緩斜面でゆるや かな連続ターンを行ったときのスノーボーダー の各関節に作用する生体内負荷を推定する一手 法について述べる. 具体的には以下の問題につ いて考える.

（1）スノーボード・ターン運動の三次元回転 運動計測, 及び雪面反力計測を行うシステム の構築

（2）関節トルクの算出

\section{3. ターンフォームの生体運動力学解析}

\section{1 解析モデルと座標系}

Fig.2 に基準座標系, Fig.3にスノーボーダー の胴体・下肢を三次元剛体リンクで仮定したモ デルと関節角度および相対座標系の定義を示 す. 基準座標系の Z 軸正方向は重力加速度方 向と一致させる.これはどんな斜面上でも重力 加速度方向は容易に求めやすく, 後の解析も簡 単に行えるようにするためである，X軸正方 向はスノーボーダーの正面方向で $\mathrm{Z}$ 軸と直交

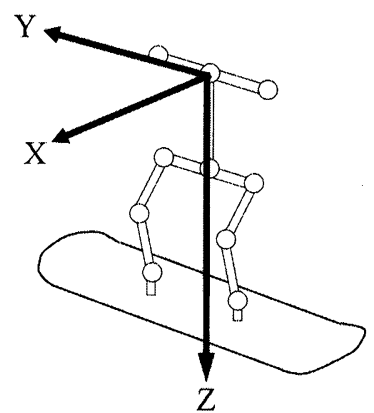

Fig.2 Global coordinate system

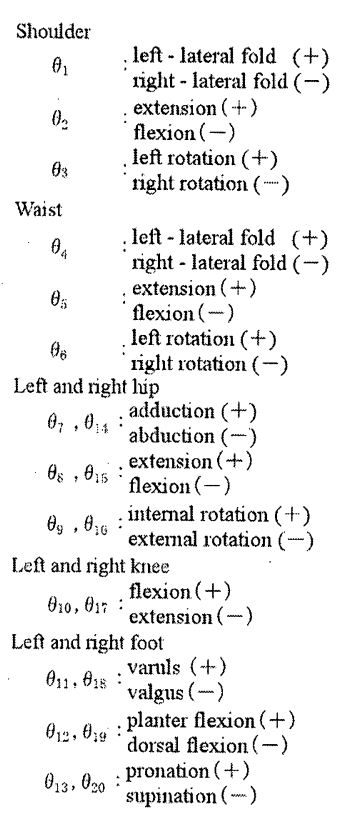

Fig.3 The 3 dimensional rigid link model and local coordinate system

するように設定する。 また Y 軸正方向は初期 姿勢の身体屈曲軸と一致する方向にする.

Fig.3 の三次元剛体リンクモデルは, 胸椎と 腰椎を連続体として考え, 第五腰椎を境にして 胴体を上体部と腰部の体節に分け，上体部，腰 部, 左右両大腿部, 下腿部および足部からなる 三次元剛体リンク機構である(10). 各リンクは 回転の 1 自由度を持ち, また, 腰椎関節・股関 節・足関節にはリンク長ゼロの仮想リンクを導 入し，自由度をそれぞれ 3 とした。 ただし腰椎 関節とは，上体部と腰部をつなぐ第五腰椎の位 置に仮想的に導入した関節を示す。関節角度は 反時計回りの正方向とした. また, 大腿部, 下 腿部, 足部の相対座標系の定義は左右同じとし すべて右手系とし， $Z$ 軸正方向はいずれも体節 下方向とした.

\section{2 オイラー角}

原点を $O_{A}$ とする基準座標系 $\Sigma_{A}\left(O_{A}-X_{A} Y_{A} Z_{A}\right)$ と一致しているある座標系を $Z_{A}$ 軸周りに角度 $\phi$ だけ回転させたものを座標系 $\Sigma_{A}{ }^{\prime}\left(O_{A}-X_{A}{ }^{\prime} Y_{A}{ }^{\prime} Z_{A}\right)$ とする. 次に $\Sigma_{A}{ }^{\prime}$ を $Y_{A}{ }^{\prime}$ 軸まわりに角度 $\theta$ だけ回 

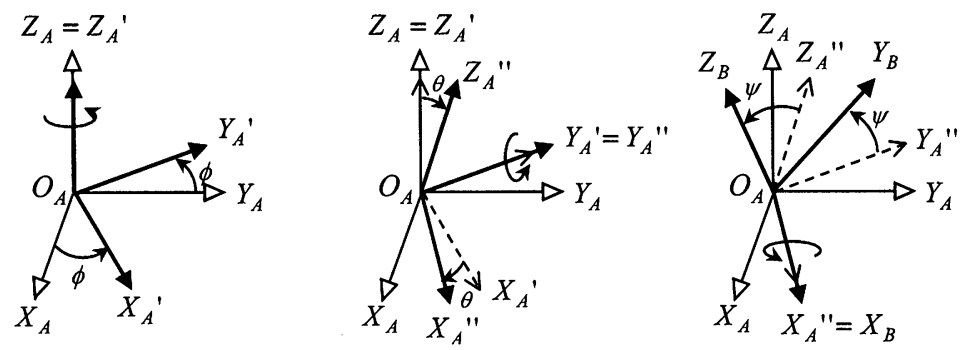

Fig.4 Euler's angle

転させたものを座標系 $\Sigma_{A}{ }^{\prime \prime}\left(O_{A}-X_{A}{ }^{\prime \prime} Y_{A}{ }^{\prime \prime} Z_{A}{ }^{\prime \prime}\right)$ とす

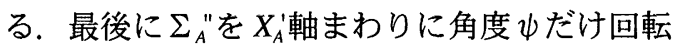
させたものを座標系 $\Sigma_{B}\left(O_{B}-X_{B} Y_{B} Z_{B}\right)$ とする. ここで, $\Sigma_{A}$ の原点 $O_{A}$ と $\Sigma_{B}$ の原点 $O_{B}$ は一致 している. この様子を Fig.4に示す.このよう な三つの回転角度の組であるオイラー角が定ま れば， $\Sigma_{A}$ から見た $\Sigma_{B}$ の姿勢は次式の回転行 列によって表現できる ${ }^{12)}$.

$\mathbf{R}(\phi) \cdot \mathbf{R}(\theta) \cdot \mathbf{R}(\psi)=\left(\begin{array}{ccc}\cos \phi & -\sin \phi & 0 \\ \sin \phi & \cos \phi & 0 \\ 0 & 0 & 1\end{array}\right)$.

$$
\left(\begin{array}{ccc}
\cos \theta & 0 & \sin \theta \\
0 & 1 & 0 \\
-\sin \theta & 0 & \cos \theta
\end{array}\right) \cdot\left(\begin{array}{ccc}
1 & 0 & 0 \\
0 & \cos \psi & -\sin \psi \\
0 & \sin \psi & \cos \psi
\end{array}\right)
$$

したがって, 初期座標 $\mathrm{p}(0)=[x(0), y(0), z$ $(0)]^{T}$ と回転後の座標 $\mathrm{p}(t)=[x(t), y(t), z(t)]^{T}$ の関係は, オイラー変換より次式で与えられる.

$$
\mathrm{p}(t)=\mathrm{R}(\phi) \cdot \mathrm{R}(\theta) \cdot \mathrm{R}(\psi) \cdot \mathrm{p}(0)
$$

\section{3 生体内負荷の推定}

各関節に作用する負荷を評価するために, ニュートン・オイラー法を適用し, 関節トル クを推定する ${ }^{12)}$. Fig.5 に示すモデルの関節卜 ルクの計算手順を示す。第 $i$ 関節の関節角度を $\theta_{i}$, 第 $i$ 関節の回転軸ベクトルを $\mathrm{S}_{i}$ とすると, 角速度ベクトル $\omega_{i}$, 角加速度ベクトル $\dot{\omega}_{i}$ は

$$
\begin{aligned}
& \omega_{i}=\omega_{i-1}+S_{i} \dot{\theta}_{i} \\
& \dot{\omega}_{i}=\dot{\omega}_{i-1}+S_{i} \ddot{\theta}_{i}+\omega_{i-1} \times\left(S_{i} \dot{\theta}_{i}\right)
\end{aligned}
$$

となる. また, 第 $i-1$ 関節から第 $i$ 関節への位 置べクトルを $\mathrm{I}_{i}$, 第 $i$ 関節から第 $i$ 節重心の位 置べクトルを $\mathrm{I}_{G i}$ とすると, 第 $i$ 関節の並進加速

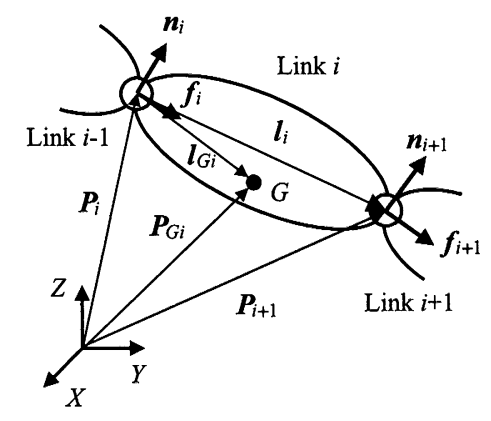

Fig.5 Force and moment to act on joint $i$

度 $\ddot{\mathrm{P}}_{i}$ と重心の加速度 $\ddot{\mathrm{P}}_{G i}$ はそれぞれ

$$
\begin{aligned}
& \ddot{\mathrm{P}}_{i}=\ddot{\mathrm{P}}_{i-1}+\dot{\omega}_{i-1} \times \mathrm{I}_{i-1}+\omega_{i-1} \times\left(\omega_{i-1} \times \mathrm{I}_{i-1}\right) \\
& \ddot{\mathrm{P}}_{G i}=\ddot{\mathrm{P}}_{i-1}+\dot{\omega}_{i} \times \mathrm{I}_{G i}+\omega_{i} \times\left(\omega_{i} \times \mathrm{I}_{G i}\right)
\end{aligned}
$$

を得る.ここで, $P_{i}$ は第 $i$ 関節の位置べクトル, $\mathrm{P}_{G i}$ は第 $i$ 節の重心位置ベクトルである．第 $i$ 節 の重心に作用する力 $\mathrm{f}_{G i}$ とモーメント $\mathrm{n}_{G i}$ は

$$
\begin{aligned}
& \mathrm{f}_{G i}=m_{i}\left(\ddot{\mathrm{P}}_{G i}-\mathrm{g}\right) \\
& \mathrm{n}_{G i}=\mathrm{I}_{i} \dot{\omega}_{i}+\omega_{i}\left(\mathrm{I}_{i} \omega_{i}\right)
\end{aligned}
$$

となる.ただし， $m_{i}$ は第 $i$ 節の質量， $I_{i}$ は重心 まわりの慣性テンソル, $\mathrm{g}=\left[\begin{array}{lll}0 & 0 & \mathrm{~g}\end{array}\right]^{T}$ は重力 加速度ベクトルである. 式（7），（8）より関節 反力 $\mathrm{f}_{i}$, 関節モーメント $n_{i}$ はそれぞれ

$$
\begin{aligned}
& \mathrm{f}_{i}=\mathrm{f}_{i+1}+\mathrm{f}_{G i} \\
& \mathrm{n}_{i}=\mathrm{n}_{i+1}+\mathrm{I}_{i} \times \mathrm{f}_{i+1}+\mathrm{I}_{G i} \times \mathrm{f}_{G i}+\mathrm{n}_{G i}
\end{aligned}
$$

とまとめられる.したがって, 関節トルクは, 関節モーメントの関節回転軸ベクトルへの投影 成分であるので, 内積で表わされ

$$
\begin{aligned}
& \tau_{i}=\mathrm{S}_{i}^{T} \mathrm{n}_{i} \\
& \tau=\left[\tau_{1}, \tau_{2}, \cdots, \tau_{n}\right]^{T}
\end{aligned}
$$

となる.ここで, 動力学的な関節トルク $て$ は, モデルを右半身と左半身に分割して考え, 右半 身, 左半身それぞれについて関節トルク $\tau_{r}, \tau_{l}$ 
を算出する. そして, 腰部のトルク $\tau_{w}$ は, 右 足からの反力によるトルク $\tau_{w r}$ と左足からの反 力によるトルク $\tau_{w l}$ から次のように求まる.

$$
\tau_{w}=\tau_{w r}+\tau_{w l}
$$

\section{4. 計測システム}

\section{1 三次元身体運動}

回転運動を計測し，順問題アプローチから並 進運動を求める. 回転運動を計測するために (制村田製作所製の圧電型振動ジャイロスター ENC-03M を用いた. スノーボード滑走中の各 身体部位の運動の角速度はジャイロセンサの 計測保証範囲を超えることが予想されるため, キャリブレーションを行った. モータの軸に ジャイロセンサを取り付け, モ一タの回転角速 度を $10 \mathrm{deg} / \mathrm{s}$ から $1800 \mathrm{deg} / \mathrm{s}$ まで徐々に上昇さ せ, ジャイロセンサの回転角速度と比較した。 結果，モータとジャイロセンサは標準偏回帰係 数 R2=0.96 で高い線形関係にあることを実験で 検証した。 したがって，本実験の計測範囲内で

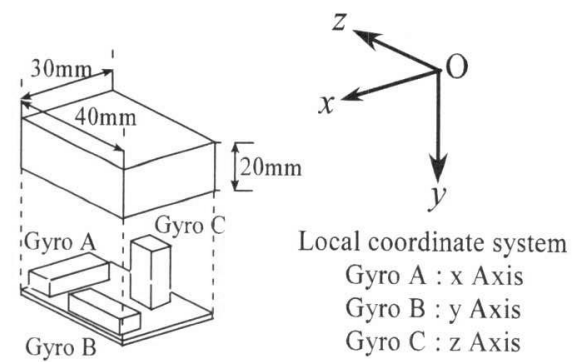

Fig.6 3-dimensional gyro sensor
十分使用できることを確認した。ジャイロセン サは 1 個につき 1 軸分の回転運動しか計測でき ない. 人間の運動は三次元空間内で行われるた め，各身体部位の回転運動を計測しなければな らない. そこでFig.6に示すようにジャイロ 3 個を直交配列し，これを 1 ユニットとして三次 元ジャイロとした ${ }^{13)}$. 三次元ジャイロセンサの 大きさは $40 \mathrm{~mm} \times 30 \mathrm{~mm} \times 20 \mathrm{~mm}$ と小型であり， スノーボードのターン運動にほとんど影響を与 えない. Fig.7 に三次元ジャイロを身体各部位 に設置した様子を示す。（a）は上体部と腰部に センサを取り付けた様子を示す。これらの部位 のセンサは, 体に密着し着脱容易なウェア型の ホルダーに取り付けて, 設置場所からのずれを 防ぐ（b）は大腿部と下腿部に，（c）は足部に 取り付けた様子をそれぞれ示す。これらの部位 のセンサはテープにより容易にずれないように 設置した.

\section{2 雪面反力}

スノーボードのターン動作を運動力学解析す るためには, 各関節の角度变位だけではなく, 身体にかかる外力も同時に計測しなければなら ない，滑走中のスノーボーダーにかかる主な外 力として, 重力, 空気抵抗, そしてボードを介 して足部に作用する雪面からの反力の 3 つが挙 げられる。この中でも，雪面反力は下肢が発生 する力, すなわち操作力と等しくなる.

本論では, 緩斜面でゆるやかな連続ターンを

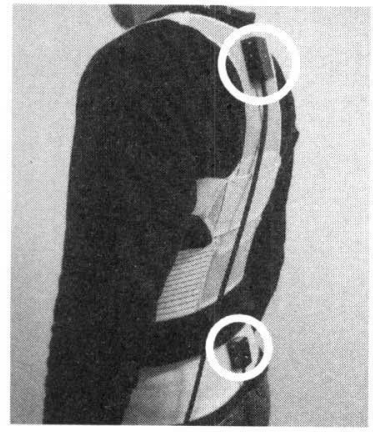

(a) Upper body and waist

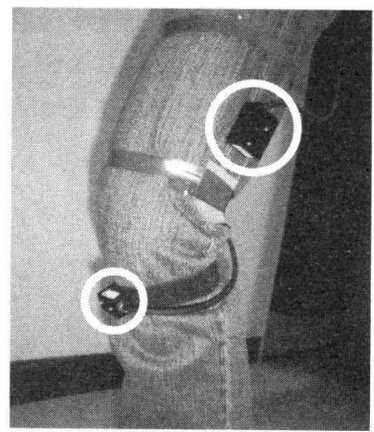

(b) Thigh and knee

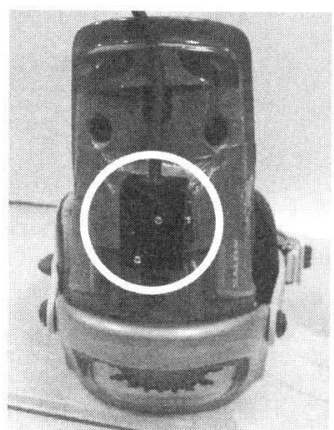

(c) Foot

Fig.7 Attachment of gyro sensors 


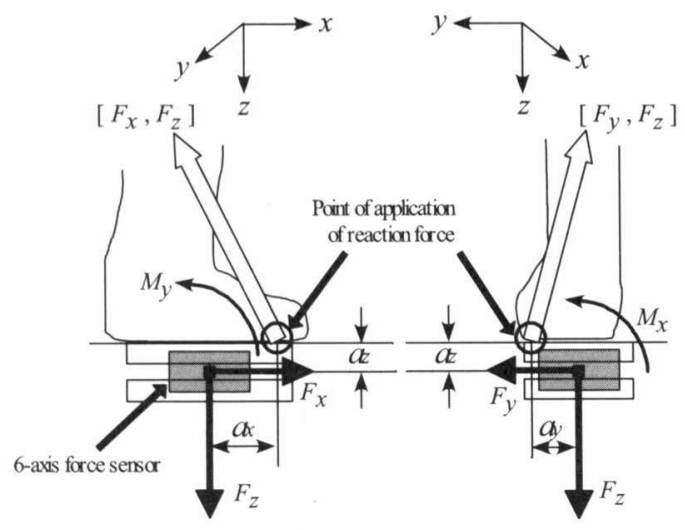

Fig.8 Reaction force and momentum

行うスノーボーダーを対象とし，二ッタ株の 6 軸力覚センサ IFS-105M50A220-I63 を用いて雪 面反力を計測する.このセンサの質量は $900 \mathrm{~g}$, 外径 $105 \mathrm{~mm}$, 高さ $51 \mathrm{~mm}$ である. センサの取 り付け方法として，ボードとバインディングに 特殊な加工を必要とせず，またバインディング とボードを自由に交換して計測できる専用のア ダプタを作成した，Fig.8で示すように，ボー ドとブーツの間に働く 3 軸方向の力 $F_{x}, F_{y}, F_{z}$ および各軸周りのモーメント $M_{x}, M_{y}, M_{z}$ を力覚 センサで計測する、これにより, 反力ベクトル $\mathrm{F}=\left[F_{v}, F_{v}, F_{z}\right]^{T}$ を求める。 また，6 軸力センサ の中心から反力作用点までの距離 $a_{x}$ と $a_{y}$ は次 式で与えられる。

$$
\begin{aligned}
& a_{x}=\frac{-F_{x} a_{z}-M_{y}}{F_{z}} \\
& a_{y}=\frac{-F_{y} a_{z}+M_{\mathrm{x}}}{F_{z}}
\end{aligned}
$$

ここで, $a_{z}$ はセンサ中心までの $\mathrm{z}$ 方向の距離 である、

\section{3 力覚センサ座標系から足部座標系への変換} 6 軸力覚センサは, バインディングに装着し ているため足部とともに移動する.したがって, 上体部を基準とする基準座標系での 6 軸力覚セ ンサに定義された座標系の姿勢を把握できなけ れば, 解析を行う際に不都合が生じる.しかし, 基準座標系に対する力覚センサの角度変化は上

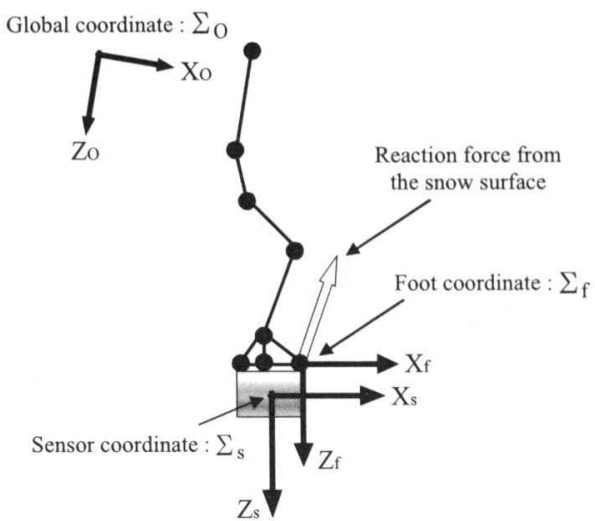

Fig.9 Relation between foot coordinate and sensor coordinate

体から足関節の全角度変化にバインディングの アングル分足した角度に等しいため, 座標変換 によって基準座標系にセンサの座標系を定義す ることができる。この座標系をセンサ座標系と し, 原点は力覚センサの中心である. 基準座標 系とセンサ座標系を Fig.9に示す.

まず，ジャイロセンサから得られる回転角度 を用い, 基準座標系から足部までの回転行列 ${ }^{0} \mathrm{R}_{a}$ が求まる.したがつて基準座標系から力覚 センサ部までの回転行列 ${ }^{0} \mathrm{R}_{s}$ は, バインディン グのアングル角度を $\theta_{B \text { in }}$ とすると

$$
{ }^{o} \mathbf{R}_{s}={ }^{o} \mathbf{R}_{a} \cdot\left[\begin{array}{ccc}
\cos \left(\theta_{B i n}\right) & -\sin \left(\theta_{B i n}\right) & 0 \\
\sin \left(\theta_{\text {Bin }}\right) & \cos \left(\theta_{B i n}\right) & 0 \\
0 & 0 & 1
\end{array}\right]
$$

となる、したがってセンサ座標系での力 $\mathrm{F}_{s}$ と モーメント $\mathrm{M}_{\mathrm{s}}$ は,

$$
\left[\begin{array}{c}
\mathrm{F}_{s} \\
\mathrm{M}_{s}
\end{array}\right]=\left[\begin{array}{cc}
{ }^{o} \mathrm{R}_{s} & 0 \\
0 & { }^{o} \mathrm{R}_{s}
\end{array}\right]^{-1}\left[\begin{array}{l}
\mathrm{F}_{0} \\
\mathrm{M}_{0}
\end{array}\right]
$$

ここで, $\mathrm{F}_{0}, \mathrm{M}_{0}$ はセンサの出力ベクトルである. 基準座標系から見たセンサ座標系，足部座標 系原点の位置ベクトル $\mathrm{P}_{s}, \mathrm{P}_{f}$ は

$$
\begin{aligned}
& \mathrm{P}_{s}=\left[\begin{array}{lll}
\mathrm{P}_{s x}, & \mathrm{P}_{s y}, & \mathrm{P}_{s z}
\end{array}\right]^{T} \\
& \mathrm{P}_{f}=\left[\begin{array}{lll}
\mathrm{P}_{f x}, & \mathrm{P}_{f y}, & \mathrm{P}_{f z}
\end{array}\right]^{T}
\end{aligned}
$$

また，センサ座標系における力とモーメントを $\mathrm{F}_{s}, \mathrm{M}_{s}$, 足部座標系における力とモーメントを $\mathrm{F}_{f}, \mathrm{M}_{f}$ とすると, 力のつり合いより $\mathrm{F}_{f}$ をセンサ 座標系の姿勢で表したものが $\mathrm{F}_{s}$ と等しくなる. 


$$
F_{s}=R F_{f}
$$

ここで， $\mathrm{R}$ はセンサ座標系から足部座標系への 回転行列であるが，座標系が等しいため単位行 列となる.

$$
\mathrm{R}=\left[\begin{array}{lll}
1 & 0 & 0 \\
0 & 1 & 0 \\
0 & 0 & 1
\end{array}\right]
$$

したがつて，モーメントのつり合いより， $\mathrm{M}_{s}$ は, $\mathrm{F}_{s}$ によって生じるモーメント $\mathrm{M}_{f}$ をセ サ座標系で表したモーメントの和となる.

$$
\begin{aligned}
\mathrm{M}_{s} & =\mathrm{RM}_{f}+\mathrm{P} \times \mathrm{F}_{s} \\
& =\mathrm{RM}_{f}+\mathrm{P} \times\left(\mathrm{RF}_{f}\right)
\end{aligned}
$$

ただし,“メ”は外積を表す。また，Pはセン サ座標系から足部座標系への位置べクトルであ る。したがって, 足部座標系からセンサ座標系 への変換行列は, 式(19), 式(21)より

$$
\left[\begin{array}{c}
\mathrm{F}_{s} \\
\mathrm{M}_{s}
\end{array}\right]=\left[\begin{array}{cc}
\mathrm{R} & 0 \\
\mathrm{P} \times \mathrm{R} & \mathrm{R}
\end{array}\right] \cdot\left[\begin{array}{c}
\mathrm{F}_{f} \\
\mathrm{M}_{f}
\end{array}\right]
$$

となる。 また，センサ座標系から足部座標系へ の变換行列は

$$
\left[\begin{array}{c}
\mathrm{F}_{f} \\
\mathrm{M}_{f}
\end{array}\right]=\left[\begin{array}{cc}
\mathrm{R} & 0 \\
\mathrm{P} \times \mathrm{R} & \mathrm{R}
\end{array}\right]^{-1}\left[\begin{array}{c}
\mathrm{F}_{s} \\
\mathrm{M}_{s}
\end{array}\right]
$$

となる.

\section{5. 実}

験

\section{1 実験方法と被験者}

被験者はスノーボード中級レベル（25歳，男 性，身長 $176 \mathrm{~cm}$, 体重 $66 \mathrm{Kg}$ ）であり，Table1 に 身体各部位の初期座標および関節トルクを求め るために必要な関節長のパラメー夕を示す。関 節トルクを求めるために, 各節の質量, 重心位 置, 慣性テンソルは阿江ら ${ }^{14)}$ にるる回帰式を参 考とした。実験にはフリースタイル用のボード

Table 1 Parameter of link model

\begin{tabular}{c|c|c|c}
\hline Parameter & Length & Parameter & Length \\
\hline$l_{0}$ & $0.39[\mathrm{~m}]$ & $w_{0}$ & $0.40[\mathrm{~m}]$ \\
\hline$l_{1}$ & $0.18[\mathrm{~m}]$ & $w_{1}$ & $0.32[\mathrm{~m}]$ \\
\hline$l_{2}$ & $0.40[\mathrm{~m}]$ & $w_{2}$ & $0.17[\mathrm{~m}]$ \\
\hline$l_{3}$ & $0.39[\mathrm{~m}]$ & $w_{3}$ & $0.20[\mathrm{~m}]$ \\
\hline$l_{4}$ & $0.06[\mathrm{~m}]$ & & \\
\hline
\end{tabular}

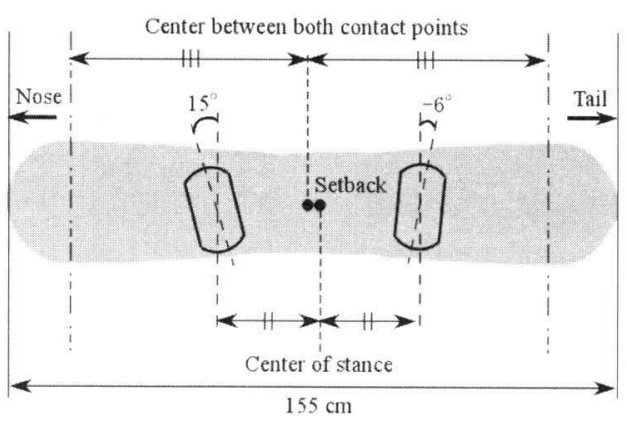

Fig.10 Setting of snowboard

（サロモン社製, $155 \mathrm{~cm}$ ) を使用した. バインディ ングの角度は Fig.10で示すように反時計回りを 正として左足を $15^{\circ}$, 右足を一 $6^{\circ}$ に設定し, セッ トバックは $0 \mathrm{~cm}$ とした。滑走条件として, 整 地された平均斜度 $20^{\circ}$ の斜面でカービングター ンを意識し，フォールライン方向に $10 \mathrm{~m}$, 横方 向に $3 \mathrm{~m}$ 間隔でポールを設置し, 滑走コースを 制限した. 1 回の滑走実験で, バックサイドター ンからフロントサイドターンへ移行する緩やか な連続ターンを 2 度行った。

\section{2 結果}

\subsection{1 角速度}

バックサイドターンからフロントサイドター ンへ移行するときの各関節の角速度を Fig.11 （a）〜（f）に示す.（a）側屈と（b）屈伸の角 速度の変化は, ターンにあわせて上体・腰を連 動させて運動している様子が読み取れる.また, （c）上体と腰部の回旋角速度は，腰部の值の方 が大きいことから, 上体と下肢でねじりが生じ, ターンの重要運動要素である「体のひねり」を 加えていることが分かる. (d) 側屈と（e）屈 伸の両下肢の角速度より, 両下肢が同調して屈 伸を行っているのがわかり, ターンの特徵を示 している. また, (f) の下肢の回旋角速度は, ター ン切り替え期付近で符号が変わつているのが分 かる、これは, バックサイドターンとフロント サイドターンで回転方向が切り替わるためであ り, 連続ターンの特徵を示している. 


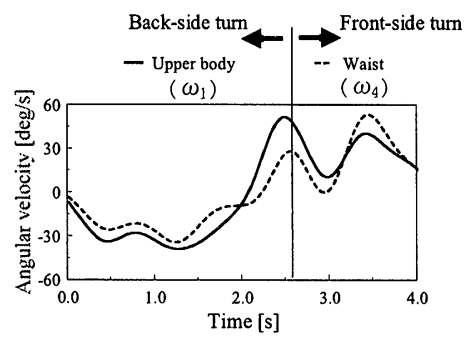

(a) Lateral fold

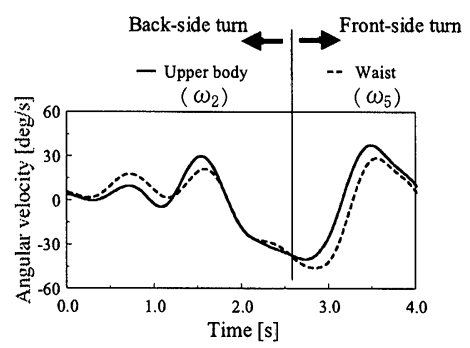

(b) Flexion and extension

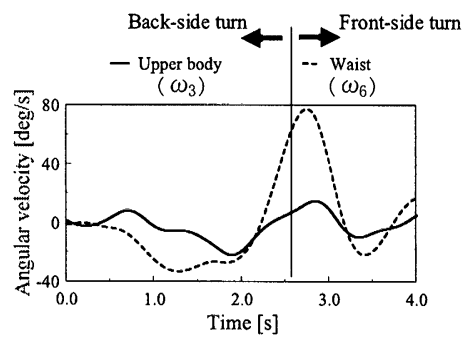

(c) Rotation

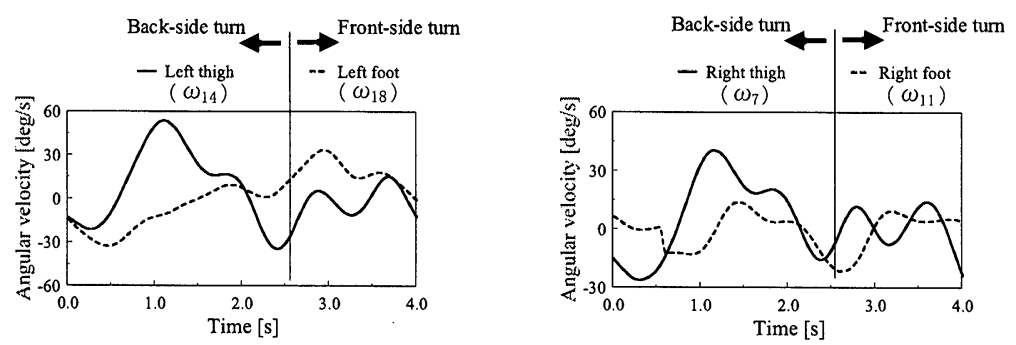

(d) Lateral fold
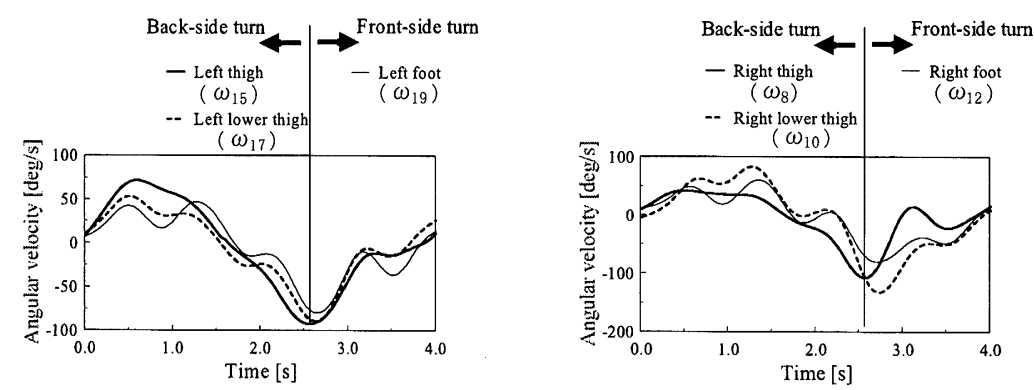

(e) Flexion and extension
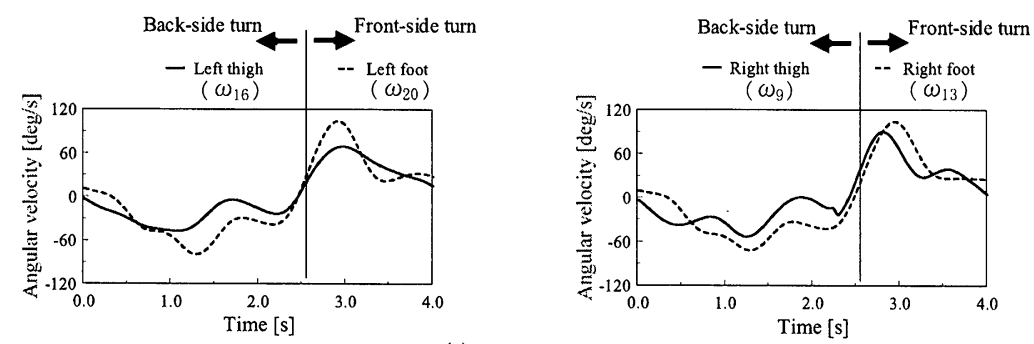

(f) Rotation

Fig.11 Angular velocities 


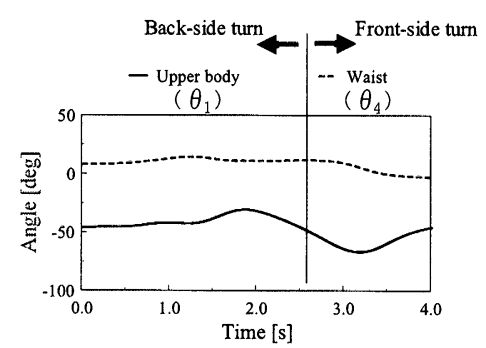

(a) Lateral fold

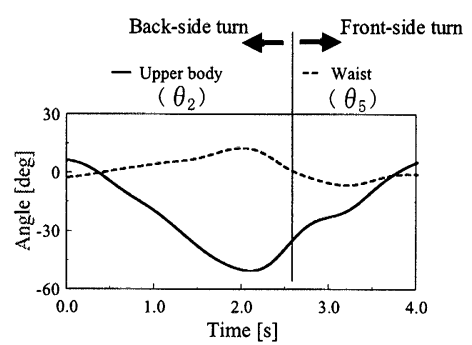

(b) Flexion and extension

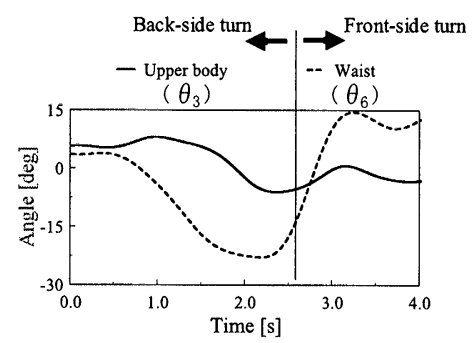

(c) Rotation
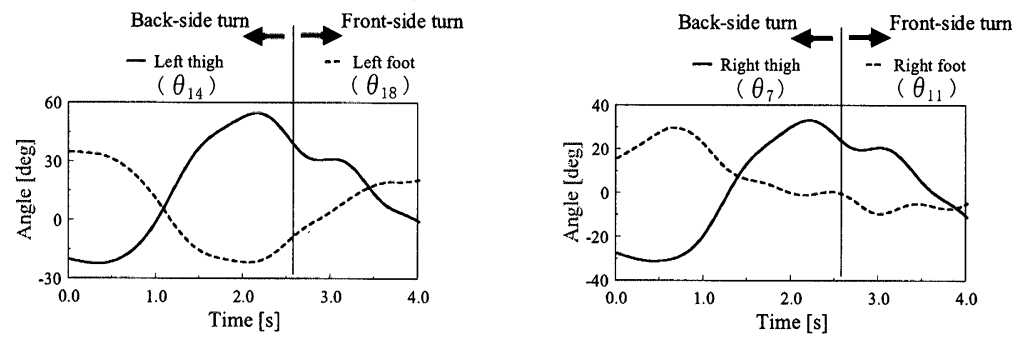

(d) Lateral fold
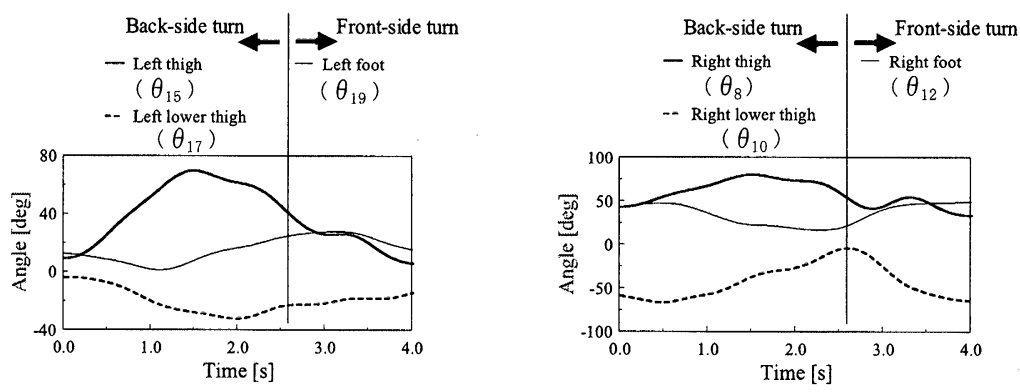

(e) Flexion and extension
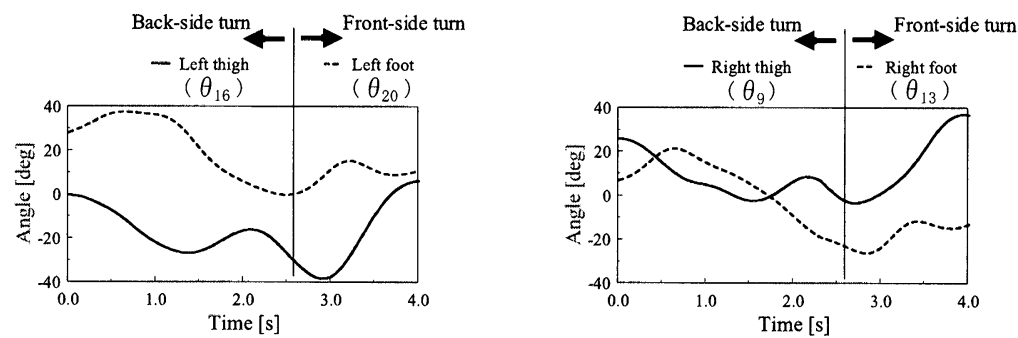

(f) Rotation

Fig.12 Angles 


\subsection{2 角度}

Fig.12（a）〜（f）に各関節の角度を示す.（a） 側屈と（b）屈伸より，腰部の側屈と屈伸の角 度変化は小さい. これはターン中に腰部をあま り運動させず，上体部に追従させていると考え られる.しかし，(c) 回旋角度では，バックサ イドターンからフロントサイドターンへ移行す る時に, 腰の回旋角度が大きく変化している.

これは, Fig.11（c）と同様にターンの重要動作 である「体のひねり」を示している.（d）の両 下肢の側屈角度より, 左右下肢が同調して側屈 を行っている. (e) 左右大腿の屈伸角度は, バッ クサイドターンで大きく, ターン切り替えを境 にしてフロントサイドターン中は減少していく

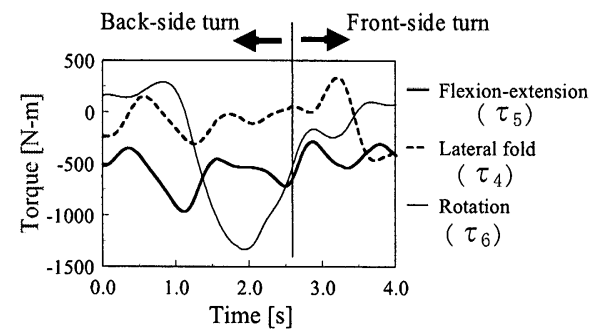

(a) Lumbar

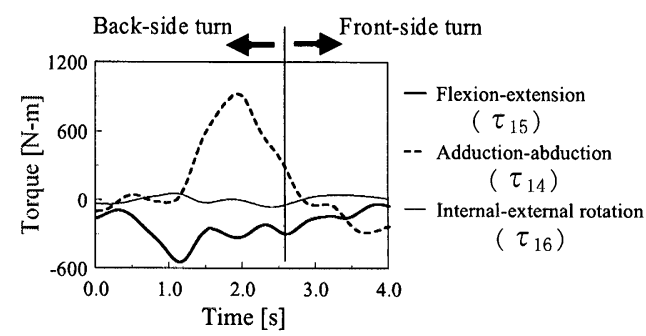

(c) Left hip

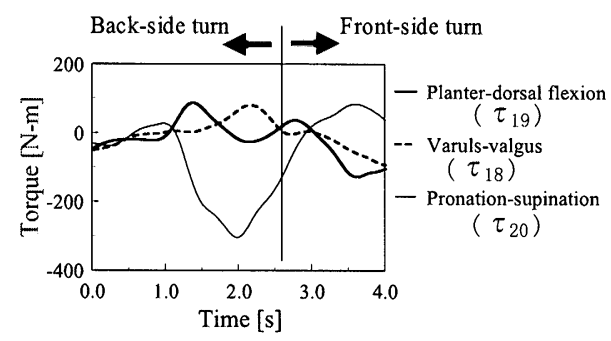

(e) Left foot
のが読み取れる.一方, 足関節の屈伸角度はバッ クサイドターン時には小さく, フロントサイド ターンでは大きくなっている.これはバックサ イドターンではバランスを取るのが難しいた め, 股関節を深く屈曲させることにより重心を 低くし安定させ，爪先をあげる足関節の背屈動 作で踵側のエッジに荷重してターンを行ってい ると考えられる。一方, フロントサイドターン では，股関節を伸展させて脚を突っ張らせ，爪 先で雪面を踏み込む足関節の底屈動作で爪先側 のエッジに荷重をかけやすくしていると考えら れる.（f）の下肢の回旋角度は，Fig.11（f） と 同様にバックサイドターンからフロントサイド ターンへの切り換え付近で符号が変わっている

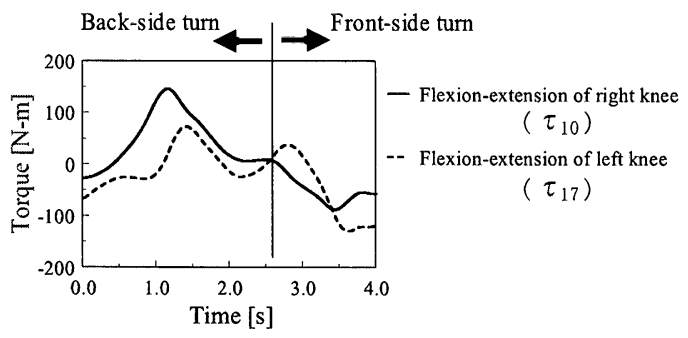

(b) Knee

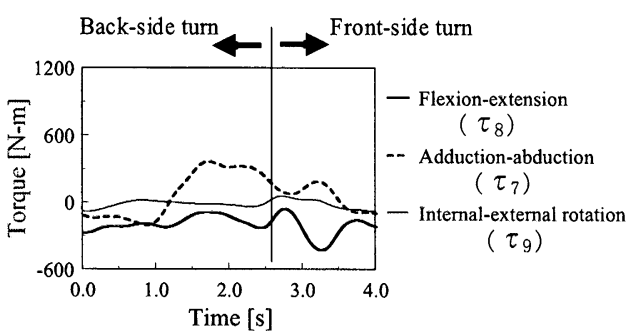

(d) Right hip

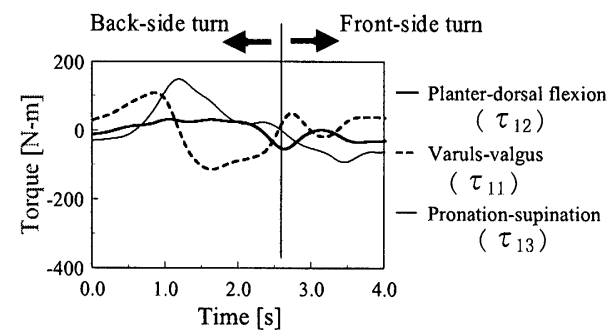

(f) Right foot

Fig.13 Joint torque 
ことから, 連続ターンの特徴を示している.

\subsection{3 関節トルク}

腰椎関節を基準座標系として各関節のトル クを推定した結果を Fig.13に示す. 各関節及 び関節軸は，Fig.3の身体相対座標系に定義し たものに従い, トルクの正負符号は右ねじの法 則により定義した．（a）の腰椎関節の回旋トル クに着目すると, バックサイドターンの前半で は右旋, 後半で左旋方向のトルクが大きく発生 している.これはバックサイドターンとフロン トサイドターンの切り替え時に, 腰をひねるこ とで次のターンを行いやすくしていると考えら れる. (b) の左右膝関節の屈伸トルクは, バッ クサイドターン時には伸展方向のトルクが発生 し, フロントサイドターン時には屈曲方向のト ルクが発生している.これは, バックサイド ターンでは, ボードの踵側で角づけするために 膝を伸展方向に運動させる力が働き, 逆にフロ ントサイドターンでは, 爪先側で角づけをする ために膝を屈曲させているためと考えられる. また，（c），(d) の左右股関節のトルクに着目 すると, バックサイドターンの左股関節のトル クが大きく発生しており, 特に, 外転トルクが 一番大きくなっている. バックサイドターンで は，股関節が深く屈伸しているので，左股関節 の外転方向への運動が体のひねりの運動となる ためであると推測できる，次に，(e)，(f) の 左右足関節の関節卜ルクでは, 底背屈トルクが 左右膝関節トルクと同様の特徵が見て取れる. これは, Fig.11 (e) と対応させることによりバッ クサイドターンでは，踵側でエッジングをする ため爪先をあげる背屈動作が行われ，フロント サイドターンでは爪先で雪面を踏み込む底屈動 作が行われるためであり，操作感覚に等しい結 果が得られた．左足では底背屈トルクはほぼ零 となっているのに対し，右足では背屈方向の卜 ルクが大きく発生している。これは, フロント サイドターンを行うときに, 背屈運動が行われ るためと考えられる。

\section{6.むす び}

本論ではスノーボードの定量的生体運動解析 を目指し, ターン運動の三次元回転運動計測, 及び雪面反力計測を行うシステムと解析方法に ついて述べた，さらに，整地された緩斜面でゆ るやかな連続ターンを行った実験範囲内でス ノーボーダーの各関節に作用する生体内負荷を 動力学的に推定する一手法について述べた．次 の結果が得られた。

(1) 三次元ジャイロセンサと6 軸力覚センサ を併用した計測システムを構築した。このシス テムを使用して，実際のスキー場でフィールド 実験を行い, スノーボーダーのターン運動と雪 面からの反力を計測した.

（2）ニュートン・オイラー法を適用し，各関 節に作用するトルクを算出した.

スノーボーダーのターン動作の各局面におけ る運動の特徵を定量化し, 生体内負荷を推定し た.これにより，個人のターン動作の特徴を定 量的・客観的に示すことが可能となり, 用具の 開発において, 聞き取り調査という定性的な設 計・開発要素を定量的に解析・評価することが 可能となる．また，スキル評価，コーチング等 の客観的な評価指標の一つとして用いることの 可能性を示した.

\section{参 考 文 献}

1 ) 坂田敏行; スノーボード操作の測定, 日本スキー 学会誌, Vol.10, No.1, pp.45-52, 2000.

2) 坂田敏行 他; スノーボードと滑走平面領域 に関する実験的研究, スポーツ産業学研究, Vol.11, No.1, pp.235-246, 2001.

3 ）坂田敏行 他; スノーボード・ターンのシミュ レーションに関する研究, 日本機械学会論文 集 C 編，Vol.65，No.639, pp.4431-4437, 1999.

4 ）清水史郎, 長谷川健治, スノーボードロボッ 卜の開発〜足関節の底屈・背屈モデル〜, ス キー研究, Vol.1, No.1, pp.9-13, 2003.

5 ）箃見武裕 他; スキー滑走における筋張力の 推定と拮抗筋作用の検討, スポーツ産業学研 究, Vol.12, No.1, pp.11-19, 2002. 
6）簟見武裕 他; スキー滑走における生体負 荷の解析手法, 日本機械学会論文集 C 編, Vol.68, No.666, pp.562-568, 2002.

7）土岐仁 他; スノーボード・ターンの運動解析 に関する研究, 日本機械学会ジョイントシンポ ジウム講演論文集 04-26, pp.261-264, 2004.

8 ) H. Doki et. al. ; Development of a measurement system for snowboarding turn analysis, The Impact of Technology on Sport, Vol.1, No.1, pp.324-329, 2005.

9）土岐仁 他 ; スノーボード・ターンの運動解析に 関する研究，日本機械学会論文集 C 編，Vol.72, No.713, pp.190-196, 2006.
10）日本エムイー学会編, 身体運動のバイオメカ ニクス, コロナ社, pp.114-125, 2002.

11）臨床歩行分析研究会, 関節モーメントによる歩 行分析, 医歯薬出版株式会社, pp.3-31, 2002.

12）吉川恒夫, ロボット制御基礎論, コロナ社, pp.11-94, 1998.

13) K. Watanabe and M. Hokari ; Kinematical Analysis and Measurement of Sports Form, IEEE Transactions on Systems, Man, and Cybernetics, Part A: Systems and Human, Volume36, Issue 3, pp.549-557, 2006.

14）安江通良他; 日本人アスリートの身体部分慣性 特性の推定, バイオメカニズム, Vol.11, No.2, pp.23-33, 1992. 